\title{
HOUSEHOLD WASTE GENERATION AND RECYCLING: SUMMARY OF EMPIRICAL RESULTS
}

In the following Tables, the empirical results reviewed in this report that relate to the household waste management sector are summarised. Table A.1 provides a brief overview of the findings related to the effectiveness of various policy instruments: if the instrument is effective at reducing waste and/or at increasing recycling, the bold font style is used and any additional note is added in brackets. Table A.2 summarises findings related to the effects of other variables, especially demographic characteristics: if the effect of a variable is significant, the bold font style is again used and the direction of the effect (positive or negative) is indicated in brackets. Table A.3 includes the various "own-price" elasticities of demand for garbage collection services that were found in the review. 
TABLE A.1: Econometric studies of the effects of policy variables on waste generation and recycling

\begin{tabular}{|c|c|c|c|}
\hline Authors (year) & Dependent variables & Independent policy variables & Data and country \\
\hline Ando and Gosselin (2005) & $\begin{array}{ll}\text { - } & \text { recycling participation of multi-family } \\
\text { dwelling households for total waste, paper, } \\
\text { and containers } \\
\text { propensity to recycle of single- and multi- } \\
\text { family dwelling (SFD and MFD) } \\
\text { households for total waste, paper, and } \\
\text { containers }\end{array}$ & $\begin{array}{l}\text { distance to bin (- for container recycling } \\
\text { propensity) }\end{array}$ & $\begin{array}{l}\text { survey data, } 214 \text { households, } \\
\text { Urbana, Illinois (USA) }\end{array}$ \\
\hline Callan and Thomas (1997) & - $\quad$ recycling rate & $\begin{array}{ll}\text { - } & \text { unit pricing (more effective if combined with } \\
\text { curbside recycling) } \\
\text { - } \\
\text { curbside recycling (more effective if combined } \\
\text { with unit pricing) } \\
\text { - } \quad \begin{array}{l}\text { free recycling at state's materials recycling } \\
\text { facility }\end{array} \\
\text { - } \quad \text { educational grants } \\
\text { - } \\
\text { - } & \text { equipment grants } \\
\text { curbside trash disposal }\end{array}$ & $\begin{array}{l}324 \text { communities, Massachusetts } \\
\text { (USA) }\end{array}$ \\
\hline
\end{tabular}




\begin{tabular}{|c|c|c|c|}
\hline Authors (year) & Dependent variables & Independent policy variables & Data and country \\
\hline Ferrara and Missios (2005) & $\begin{array}{l}\text { probability of recycling newspaper, glass, } \\
\text { plastic, aluminum, tin/steel cans, } \\
\text { cardboard, and toxic chemicals }\end{array}$ & $\begin{array}{l}\text { - } \quad \text { unit price (with the exception of toxic chemicals } \\
\text { as they are not subject to the fee) } \\
\text { - } \quad \text { weekly recycling (only for glass, aluminum, and } \\
\text { toxic chemicals) } \\
\text { - } \quad \text { free units (intensity of recycling declines) } \\
\text { - unit limit (intensity of recycling declines for } \\
\text { plastic and toxic chemicals) } \\
\text { - mandatory recycling (with the exception of glass) }\end{array}$ & $\begin{array}{l}\text { survey data, } 1409 \text { households, } \\
\text { Ontario (Canada) }\end{array}$ \\
\hline $\begin{array}{l}\begin{array}{l}\text { Fullerton and Kinnaman } \\
\text { (1996) }\end{array} \\
\end{array}$ & $\begin{array}{ll}- & \text { garbage weight } \\
\text { - } & \text { garbage volume } \\
\text { - } & \text { garbage density (weight per can) } \\
\text { - } & \text { recycling (weight) }\end{array}$ & $\begin{array}{ll} & \text { bag-based user fee (but density increases) }\end{array}$ & $\begin{array}{l}\text { actual measurements of garbage } \\
\text { and recycling over } 8 \text { weeks, mail } \\
\text { survey for demographic } \\
\text { information, } 75 \text { households, } \\
\text { Charlottesville, Virginia (USA) }\end{array}$ \\
\hline Hong (1999) & $\begin{array}{ll}\text { - } & \text { total waste } \\
\text { - } & \text { recyclables }\end{array}$ & - $\quad$ bag-based user fee (only for recyclables) & $\begin{array}{l}\text { survey data, } 3017 \text { households, } \\
\text { Korea }\end{array}$ \\
\hline Hong and Adams (1999) & $\begin{array}{ll}\text { - } & \text { probability of contracting for larger } \\
\text { - } & \text { nolume } \\
\text { - } & \text { non-recyclable waste } \\
\text { - } & \text { recyclable waste } \\
\end{array}$ & $\begin{array}{l}\text { - payment difference (no effect on choice of } \\
\text { container size) }\end{array}$ & 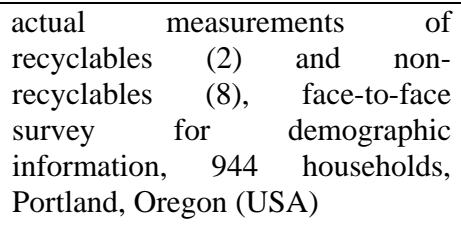 \\
\hline Hong et al. (1993) & $\begin{array}{ll}- & \text { frequency of recycling participation } \\
\text { - } & \text { garbage }\end{array}$ & $\begin{array}{l}\text { disposal fee under block payment system (for } \\
\text { recycling) }\end{array}$ & $\begin{array}{l}\text { survey data, } 2298 \text { households, } \\
\text { Portland, Oregon (USA) }\end{array}$ \\
\hline Jenkins (1993) & $\begin{array}{l}\text { - } \quad \text { quantity of discarded waste } \\
\end{array}$ & - $\quad$ user fee & $\begin{array}{l}\begin{array}{l}\text { community-level, } \\
\text { (USA) }\end{array} \\
\text { panel data }\end{array}$ \\
\hline
\end{tabular}




\begin{tabular}{|c|c|c|c|}
\hline Authors (year) & Dependent variables & Independent policy variables & Data and country \\
\hline Jenkins et al. (2003) & $\begin{array}{l}\text { probability of recycling newspaper, glass } \\
\text { bottles, aluminum, plastic bottles, and yard } \\
\text { waste }\end{array}$ & $\begin{array}{ll}\text { - } & \text { disposal price } \\
\text { - } & \text { curbside program (more effective than drop-off } \\
\text { program) } \\
\text { drop-off program (less effective than curbside } \\
\text { program) } \\
\text { number of curbside collected materials (only for } \\
\text { newspaper) } \\
\text { - } \quad \begin{array}{l}\text { mandatory curbside recycling } \\
\text { experience with recycling program (only for }\end{array} \\
\text { newspaper; for yard waste only if program is over } \\
2 \text { years old) }\end{array}$ & $\begin{array}{l}\text { survey data, } 1049 \text { households, } \\
\text { USA }\end{array}$ \\
\hline Judge and Becker (1993) & - $\quad$ diversion (number of bins of recyclables) & $\begin{array}{ll}\text { - } & \text { frequency } \\
\text { - } & \text { commingled } \\
\text { - } & \text { accessible pick-up location } \\
\text { - } & \text { special recycling education }\end{array}$ & $\begin{array}{l}\text { controlled field experiment, with } \\
\text { actual measurements of recycling } \\
\text { volume of participating } \\
\text { households over } 6 \text { months, door- } \\
\text { to-door survey of households for } \\
\text { demographic information, Rice } \\
\text { County, Minnesota (USA) }\end{array}$ \\
\hline $\begin{array}{l}\text { Kinnaman and } \text { Fullerton } \\
(2000)\end{array}$ & $\begin{array}{ll}- & \text { garbage } \\
\text { - } & \text { recyclable waste }\end{array}$ & $\begin{array}{ll}- & \text { user fee per bag (ineffective with subscription } \\
& \text { programs) } \\
\text { - } & \text { free curbside recycling (only for recycling) } \\
\text { - } & \text { refundable deposit system } \\
\text { - } & \text { yard waste ban (only for recycling) } \\
\text { - } & \text { mandatory recycling (only for garbage) }\end{array}$ & 959 communities, USA \\
\hline Linderhof et al. (2001) & $\begin{array}{ll}- & \text { compostable waste } \\
\text { - } & \text { non-recyclable waste }\end{array}$ & 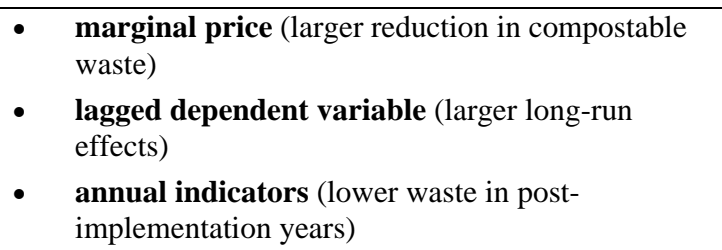 & $\begin{array}{l}3 \quad 437 \text { households surveyed } \\
\text { between } 2 \text { and } 42 \text { times, Oostzaan, } \\
\text { the Netherlands }\end{array}$ \\
\hline
\end{tabular}




\begin{tabular}{|c|c|c|c|}
\hline Authors (year) & Dependent variables & Independent policy variables & Data and country \\
\hline Nestor and Podolsky (1998) & $\begin{array}{ll}\text { - } & \text { total waste } \\
\text { - } & \text { waste set out at curbside } \\
\text { - } & \text { waste disposed of on site } \\
\text { - } & \text { waste transported off site } \\
\text { - } & \text { recyclables set out at curbside } \\
\text { - } & \text { recyclables disposed of on site } \\
\text { - } & \text { recyclables transported off site }\end{array}$ & $\begin{array}{l}\text { - can-based user fee (+ for recycling and total } \\
\text { waste; - for trash) } \\
\text { bag-based user fee (+ for curbside recycling but } \\
\text { less effectively than bag-based system; - for } \\
\text { curbside trash but more effectively than can-based } \\
\text { system) } \\
\text { indicator for presence of garbage disposal (+ for } \\
\text { trash) }\end{array}$ & $\begin{array}{l}284 \text { households surveyed twice, } \\
\text { city of Marietta, Georgia (USA) }\end{array}$ \\
\hline Podolsky and Spiegel (1998) & $\begin{array}{l}\text { quantity of solid waste disposed of per } \\
\text { capita }\end{array}$ & $\begin{array}{l}\text { - } \\
\text { - } \\
\text { quantit price } \\
\text { mandatory; effect is independent of whether unit } \\
\text { pricing is in place) }\end{array}$ & $\begin{array}{l}149 \text { communities, five New Jersey } \\
\text { counties (USA) }\end{array}$ \\
\hline Reschovsky and Stone (1994) & $\begin{array}{l}\text { probability of recycling (in terms of } \\
\text { whether households recycle) newspaper, } \\
\text { glass, plastic, cardboard, metal, and } \\
\text { food/yard waste (composting) }\end{array}$ & 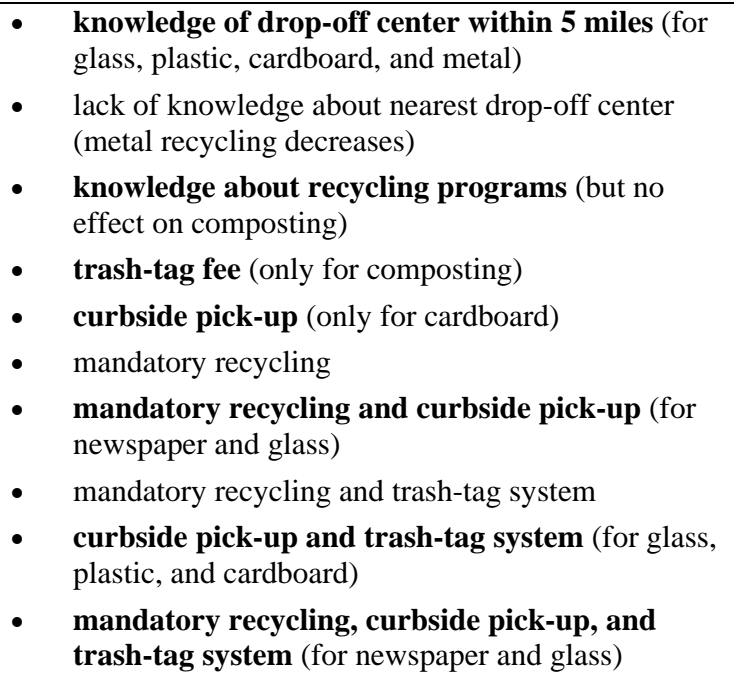 & $\begin{array}{l}\text { survey data, } 1422 \text { households, } \\
\text { Tompkins County, USA }\end{array}$ \\
\hline Sterner and Bartelings (1999) & $\begin{array}{l}\text { recycling of various materials (glass, } \\
\text { paper, refundable, batteries, hazardous } \\
\text { waste, household machines, and textiles) }\end{array}$ & $\begin{array}{ll}\text { - } & \text { indicator for municipality with weight-based fee } \\
\text { (only for glass) } \\
\text { - } \\
\text { indicator for municipality with frequency-based } \\
\text { fee (only for glass) }\end{array}$ & $\begin{array}{l}\text { household survey data from three } \\
\text { Swedish communities with } \\
\text { different fee structures (weight- or } \\
\text { frequency-based fee and flat fee) }\end{array}$ \\
\hline
\end{tabular}




\begin{tabular}{|l|l|l|l|}
\hline Authors (year) & Dependent variables & Independent policy variables \\
\hline $\begin{array}{l}\text { Van Houtven and Morris } \\
(1999)\end{array}$ & $\begin{array}{l}\text { mixed waste } \\
\text { probability of recycling } \\
\text { total waste (mixed plus recyclables) }\end{array}$ & $\begin{array}{l}\text { Data and country } \\
\text { bag program dummy (stronger effect than can } \\
\text { program for mixed and total waste) } \\
\text { can program dummy (weaker effect than can } \\
\text { program for mixed and total waste) } \\
\text { interaction between unit pricing and home } \\
\text { ownership (smaller effect among home-owners) } \\
\text { interaction between unit pricing and number of } \\
\text { residents (larger effect in households with many } \\
\text { residents) }\end{array}$ \\
\hline
\end{tabular}


TABLE A.2: Econometric studies of the effects of demographic and attitudinal variables on waste generation and recycling

\begin{tabular}{|c|c|c|c|}
\hline $\begin{array}{l}\text { Authors } \\
\text { (year) }\end{array}$ & Dependent variables & $\begin{array}{c}\begin{array}{c}\text { Independent variables other than policy variables (mostly } \\
\text { demographic characteristics) }\end{array}\end{array}$ & Data and country \\
\hline Ando and Gosselin (2005) & $\begin{array}{l}\text { recycling participation of } \\
\text { multi-family dwelling } \\
\text { households for total waste, } \\
\text { paper, and containers } \\
\text { propensity to recycle of single- } \\
\text { and multi-family dwelling } \\
\text { (SFD and MFD) households for } \\
\text { total waste, paper, and } \\
\text { containers }\end{array}$ & 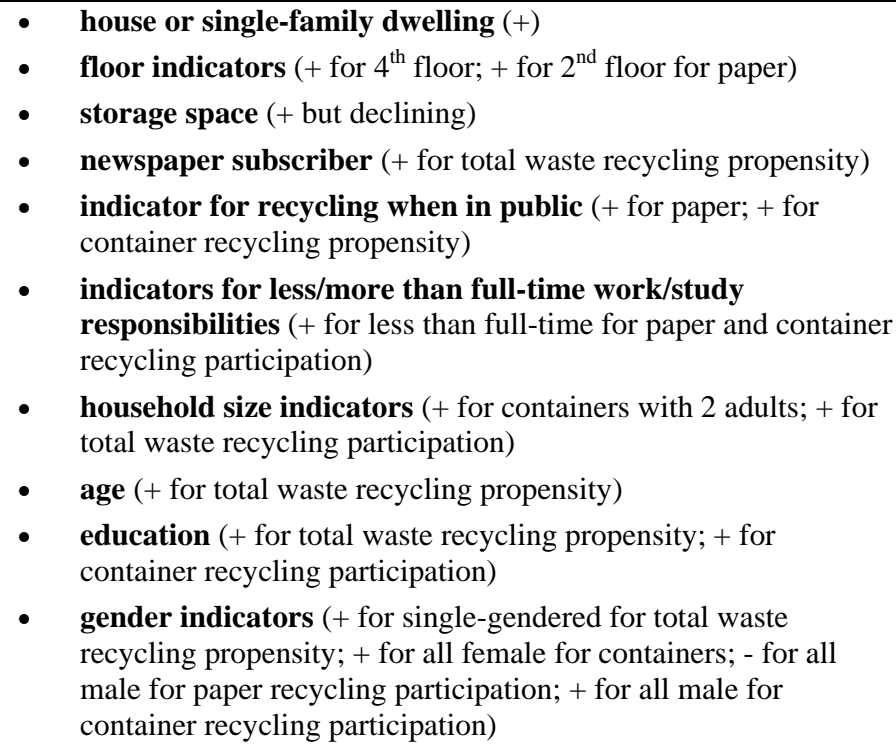 & $\begin{array}{l}\text { survey data, } 214 \text { households, } \\
\text { Urbana, Illinois (USA) }\end{array}$ \\
\hline Callan and Thomas (1997) & - $\quad$ recycling rate & $\begin{array}{ll}\text { - } & \text { income }(+) \\
\text { - } & \text { education (+ but declining) } \\
\text { - } & \text { housing value } \\
\text { - } & \text { housing age }(+) \\
\text { - } & \text { density }(-) \\
\text { - } & \text { population (- but declining) } \\
\text { - } & \text { suburban/rural economic center } \\
\text { - } & \text { resort/retirement/small rural community }(+)\end{array}$ & $\begin{array}{l}324 \text { communities, Massachusetts } \\
\text { (USA) }\end{array}$ \\
\hline
\end{tabular}




\begin{tabular}{|c|c|c|c|}
\hline $\begin{array}{l}\text { Authors } \\
\text { (year) }\end{array}$ & Dependent variables & $\begin{array}{c}\text { Independent variables other than policy variables (mostly } \\
\text { demographic characteristics) }\end{array}$ & Data and country \\
\hline $\begin{array}{l}\text { Dijkgraaf and Gradus } \\
\text { (2004) }\end{array}$ & $\begin{array}{ll}- & \text { total waste } \\
\text { - } & \text { unsorted waste } \\
\text { - } & \text { compostable waste } \\
\text { - } & \text { recyclable waste }\end{array}$ & $\begin{array}{ll}\text { - } & \text { age (+ for total and compostable) } \\
\text { - } & \text { size (- for total and unsorted; + for compostable and recyclable) } \\
\text { - } & \text { proportion of foreigners (- for every waste stream but } \\
\text { unsorted) } \\
\text { - } & \text { city (- for every waste stream but unsorted) } \\
\text { - } & \text { village (- for unsorted; + for compostable and recyclable) } \\
\text { - } & \text { population density (+ for every waste stream but recyclable) } \\
\text { - } & \text { home ownership (+ for every waste stream but recyclable) } \\
\text { - } & \text { flat ownership (- for every waste stream but unsorted) } \\
\text { - } & \text { income (+ for total and unsorted) }\end{array}$ & $\begin{array}{l}\text { Community-level, panel data, the } \\
\text { Netherlands }\end{array}$ \\
\hline Ferrara and Missios (2005) & $\begin{array}{l}\text { probability of recycling } \\
\text { newspaper, glass, plastic, } \\
\text { aluminum, tin/steel cans, } \\
\text { cardboard, and toxic chemicals }\end{array}$ & 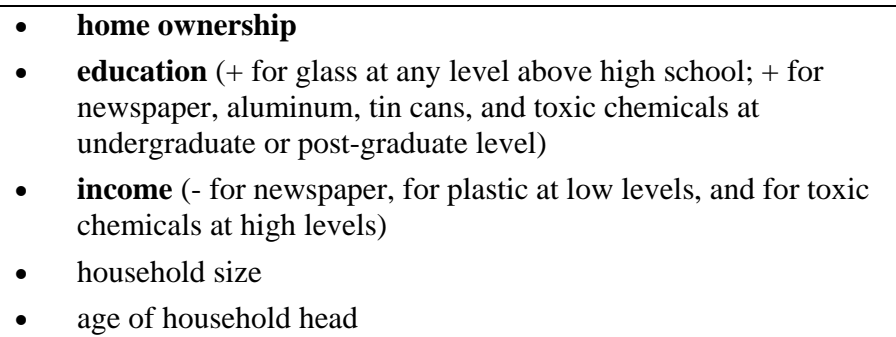 & $\begin{array}{l}\text { survey data, } 1409 \text { households, } \\
\text { Ontario (Canada) }\end{array}$ \\
\hline $\begin{array}{l}\text { Fullerton and Kinnaman } \\
\text { (1996) }\end{array}$ & $\begin{array}{ll}- & \text { decrease in garbage weight } \\
\text { - } & \text { decrease in garbage volume } \\
\text { - } & \text { increase in garbage density } \\
& \text { (weight per can) } \\
\text { - } & \text { increase in recycling (weight) }\end{array}$ & $\begin{array}{ll}\text { - } & \text { number of newspapers delivered daily (+ for garbage weight } \\
\text { and volume and for recycling) } \\
\text { - } \\
\text { fraction of household less than } 3 \text { years of age (+ for garbage } \\
\text { weight and volume) } \\
\text { - } \quad \text { college } \\
\text { - } & \text { income (- for garbage) } \\
\text { - } & \text { indicator for adult married couple (+ for garbage) } \\
\text { - } & \text { indicator for white household (- for recycling) }\end{array}$ & $\begin{array}{l}\text { actual measurements of garbage } \\
\text { and recycling over } 8 \text { weeks, mail } \\
\text { survey for } \text { demographic } \\
\text { information, } 75 \text { households, } \\
\text { Charlottesville, Virginia (USA) }\end{array}$ \\
\hline
\end{tabular}




\begin{tabular}{|c|c|c|c|}
\hline $\begin{array}{l}\text { Authors } \\
\text { (year) }\end{array}$ & Dependent variables & $\begin{array}{c}\text { Independent variables other than policy variables (mostly } \\
\text { demographic characteristics) }\end{array}$ & Data and country \\
\hline Hong (1999) & $\begin{array}{ll}- & \text { total waste } \\
\text { - } & \text { recyclables }\end{array}$ & $\begin{array}{ll}\text { - } & \text { income (+ for total waste) } \\
\text { - } & \text { size (+ for total waste) } \\
\text { - } & \text { education (+ for recyclables) } \\
\text { - } & \text { opportunity cost of time (- for recyclables) } \\
\text { - } & \text { recycling rate (+ for total waste) } \\
\text { - } & \text { waste generation (+ for recyclables) }\end{array}$ & $\begin{array}{l}\text { survey data, } 3017 \text { households, } \\
\text { Korea }\end{array}$ \\
\hline Hong and Adams (1999) & $\begin{array}{ll}\text { - } & \text { probability of contracting for } \\
\text { - } & \text { larger volume } \\
\text { - } & \text { recyclacyclable waste } \\
\text { - } & \text { recycling rate }\end{array}$ & $\begin{array}{ll}\text { - } & \text { income } \\
\text { - } & \text { household size (+ for non-recyclables and probability of larger } \\
\text { - } & \text { holume; - for recycling rate) } \\
\text { - } & \text { education level } \\
\text { - } & \text { presence of garage (- for non-recyclables) } \\
\text { - } & \text { presence of small children (+ for non-recyclables; - for } \\
& \text { probability of larger volume and recycling rate) } \\
\text { - } & \text { seasonal indicators (relative to winter, + for non-recyclables } \\
& \text { always; + for recyclables and recycling rate only in the autumn) }\end{array}$ & $\begin{array}{l}\text { actual measurements of } \\
\text { recyclables }(2) \text { and non- } \\
\text { recyclables (8), face-to-face } \\
\text { survey for } \text { demographic } \\
\text { information, } 944 \text { households, } \\
\text { Portland, Oregon (USA) }\end{array}$ \\
\hline Hong et al. (1993) & $\begin{array}{ll}\text { - } & \text { frequency of recycling } \\
& \text { participation } \\
\text { - } & \text { garbage }\end{array}$ & $\begin{array}{ll}\text { - } & \text { number of people }(+) \\
\text { - } & \text { education (+ for recycling) } \\
\text { - } & \text { non-white (- for recycling; + for garbage) } \\
\text { - } & \text { home rental (- for recycling, + for garbage) } \\
\text { - } & \text { value of time (- for recycling) } \\
\text { - } & \text { income (+ for garbage) }\end{array}$ & $\begin{array}{l}\text { survey data, } 2298 \text { households, } \\
\text { Portland, Oregon (USA) }\end{array}$ \\
\hline Jenkins (1993) & $\begin{array}{ll}- & \text { quantity of discarded waste }\end{array}$ & $\begin{array}{ll}\text { - } & \text { average household income }(+) \\
\text { - } & \text { mean temperature }(+) \\
\text { - } & \text { average precipitation }(+) \\
\text { - } & \text { average household size }(-) \\
\text { - } & \text { proportion of population } 18 \text { to } 49 \text { years of age }(+) \\
\text { - } & \text { population density }(+) \\
\text { - } & \text { price received for old newspapers }\end{array}$ & $\begin{array}{l}\text { community-level, panel data } \\
\text { (USA) }\end{array}$ \\
\hline
\end{tabular}




\begin{tabular}{|c|c|c|c|}
\hline $\begin{array}{l}\text { Authors } \\
\text { (year) }\end{array}$ & Dependent variables & $\begin{array}{l}\text { Independent variables other than policy variables (mostly } \\
\text { demographic characteristics) }\end{array}$ & Data and country \\
\hline Jenkins et al. (2003) & 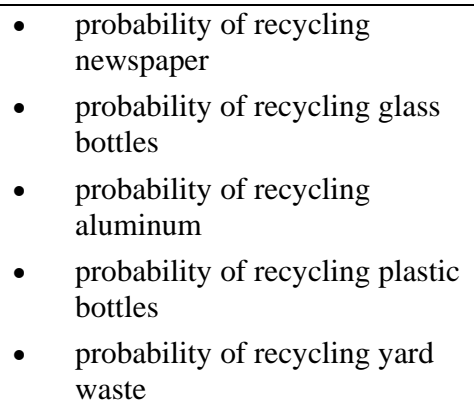 & $\begin{array}{ll}\text { - } & \text { population density (- for yard waste) } \\
\text { - } & \text { income }(+) \\
\text { - } & \text { household size (+ for glass bottles and yard waste) } \\
\text { - } & \text { age of household head (+ for all materials but glass bottles) } \\
\text { - } & \text { single-family dwellings (+ for plastic bottles and yard waste) } \\
\text { - } & \text { home ownership (+ for glass bottles and aluminum) } \\
\text { - } & \text { education (+ for newspaper, glass bottles, and aluminum; } \\
\text { college education has smaller effect than high school education } \\
\text { for glass bottles) }\end{array}$ & $\begin{array}{l}\text { survey data, } 1049 \text { households, } \\
\text { USA }\end{array}$ \\
\hline Judge and Becker (1993) & $\begin{array}{l}\text { - diversion (number of bins of } \\
\text { recyclables) }\end{array}$ & $\begin{array}{ll}- & \text { household size }(+) \\
\text { - } & \text { average adult age } \\
\text { - } & \text { home rental } \\
\text { - } & \text { education (+ only at college and graduate level) }\end{array}$ & $\begin{array}{l}\text { controlled field experiment, with } \\
\text { actual measurements of recycling } \\
\text { volume of participating } \\
\text { households over } 6 \text { months, door- } \\
\text { to-door survey of households for } \\
\text { demographic information, Rice } \\
\text { County, Minnesota }\end{array}$ \\
\hline $\begin{array}{l}\text { Kinnaman and Fullerton } \\
(2000)\end{array}$ & $\begin{array}{ll} & \text { garbage } \\
\text { - } & \text { recyclable waste }\end{array}$ & $\begin{array}{ll}- & \text { income (+ for garbage) } \\
\text { - } & \text { age (+ for recycling) } \\
\text { - } & \text { household size (+ for recycling) } \\
\text { - } & \text { education (- for garbage; + for recycling) } \\
\text { - } & \text { home ownership (+ for recycling) } \\
\text { - } & \text { population density (- for recycling) }\end{array}$ & 959 communities, USA \\
\hline Linderhof et al. (2001) & $\begin{array}{ll}\text { - } & \text { compostable waste } \\
\text { - } & \text { non-recyclable waste }\end{array}$ & $\begin{array}{ll}\text { - } & \text { size }(+) \\
\text { - } & \text { age }(- \text { but declining for non-recyclable waste) } \\
\text { - } & \text { share of females }(+) \\
\text { - } & \text { children by age group (+ for compostable waste; + for non- } \\
& \text { recyclable waste only with infants from } 0 \text { to } 2 \text { years old and - } \\
& \text { otherwise) } \\
\text { - } & \text { temperature }(+) \\
\text { - } & \text { seasonal indicators (- relative to first quarter) }\end{array}$ & $\begin{array}{l}3 \quad 437 \text { households surveyed } \\
\text { between } 2 \text { and } 42 \text { times, Oostzaan, } \\
\text { the Netherlands }\end{array}$ \\
\hline
\end{tabular}




\begin{tabular}{|c|c|c|c|}
\hline $\begin{array}{l}\text { Authors } \\
\text { (year) }\end{array}$ & Dependent variables & $\begin{array}{c}\text { Independent variables other than policy variables (mostly } \\
\text { demographic characteristics) }\end{array}$ & Data and country \\
\hline Nestor and Podolsky (1998) & $\begin{array}{ll}\text { - } & \text { total waste } \\
\text { - } & \text { waste set out at curbside } \\
\text { - } & \text { waste disposed of on site } \\
\text { - } & \text { waste transported off site } \\
\text { - } & \text { recyclables set out at curbside } \\
\text { - } & \text { recyclables disposed of on site } \\
\text { - } & \text { recyclables transported off site }\end{array}$ & 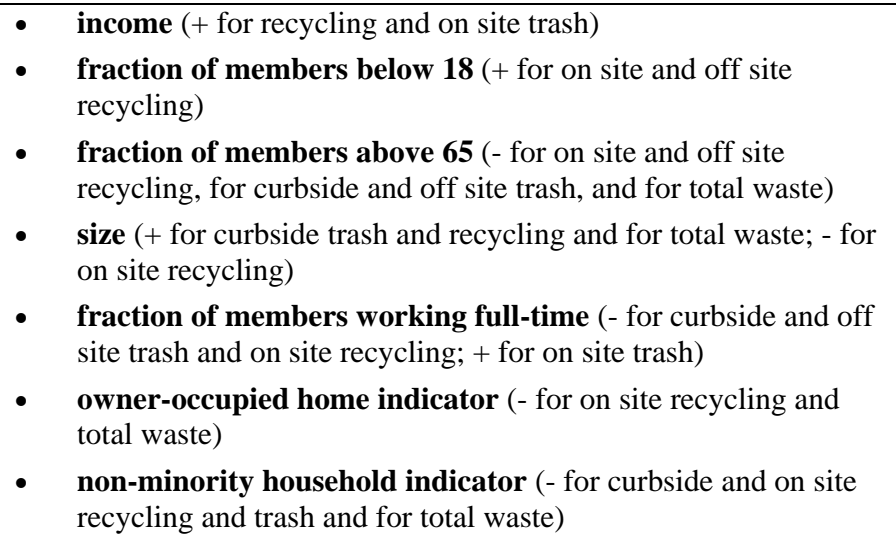 & $\begin{array}{l}284 \text { households surveyed twice, } \\
\text { City of Marietta, GA (USA) }\end{array}$ \\
\hline $\begin{array}{l}\text { Podolsky and Spiegel } \\
\text { (1998) }\end{array}$ & $\begin{array}{l}\text { - } \quad \text { quantity of solid waste } \\
\text { disposed of per capita }\end{array}$ & $\begin{array}{ll}\text { - } & \text { income }(+) \\
\text { - } & \text { age }(-) \\
\text { - } & \text { size }(- \text { but declining) } \\
\text { - } & \text { population density }(-) \\
\text { - } & \text { rain }(+) \\
\text { - } & \text { snow }(-) \\
\text { - } & \text { number of employees per household (+ but declining) }\end{array}$ & $\begin{array}{l}149 \text { communities, five New Jersey } \\
\text { counties (USA) }\end{array}$ \\
\hline $\begin{array}{l}\text { Reschovsky and Stone } \\
\text { (1994) }\end{array}$ & $\begin{array}{l}\text { probability of recycling (in } \\
\text { terms of whether households } \\
\text { recycle) newspaper, glass, } \\
\text { plastic, cardboard, metal, and } \\
\text { food/yard waste (composting) }\end{array}$ & $\begin{array}{ll}\text { - } & \text { adequate storage (+ for glass, plastic, cardboard, and metal) } \\
\text { - } & \text { household size (- for newspaper; + for composting) } \\
\text { - } & \text { married (+ for newspaper, glass, metal, and composting) } \\
\text { - } & \text { age (- for cardboard; + for composting) } \\
\text { - } & \text { education (+) } \\
\text { - } & \text { weekly number of paid labour hours (- for newspaper) } \\
\text { - } & \text { income (- for glass and plastic) }\end{array}$ & $\begin{array}{l}\text { survey data, } 1422 \text { households, } \\
\text { Tompkins County (USA) }\end{array}$ \\
\hline
\end{tabular}




\begin{tabular}{|c|c|c|c|}
\hline $\begin{array}{l}\text { Authors } \\
\text { (year) }\end{array}$ & Dependent variables & $\begin{array}{l}\text { Independent variables other than policy variables (mostly } \\
\text { demographic characteristics) }\end{array}$ & Data and country \\
\hline $\begin{array}{l}\text { Richardson and Havlicek } \\
\text { (1978) }\end{array}$ & $\begin{array}{l}\text { - } \\
\text { components }\end{array}$ & $\begin{array}{l}\text { average household income (+ for green glass, aluminum, } \\
\text { newspaper, grass, and total; - for textiles, plastics, and } \\
\text { garbage/other) } \\
\text { average household size (+ for clear and green glass, aluminum, } \\
\text { metals, textiles, other paper, plastics, garbage/other, and total) } \\
\text { percentage of people between } 18 \text { and } \mathbf{6 1} \text { years of age (+ for } \\
\text { clear and green glass, aluminum, metals, other paper, plastics, } \\
\text { and total) }\end{array}$ & $\begin{array}{l}\text { aggregated household data (60 to } \\
90 \text { households) in } 24 \text { areas of } \\
\text { Indianapolis (USA) }\end{array}$ \\
\hline $\begin{array}{l}\text { Sterner and Bartelings } \\
\text { (1999) }\end{array}$ & $\begin{array}{ll}- & \text { total garbage } \\
\text { - } & \text { composted kitchen waste } \\
\text { - } & \text { recycling of various materials } \\
\text { (glass, paper, refundables, } \\
\text { batteries, hazardous waste, } \\
\text { household machines, and } \\
\text { textiles) }\end{array}$ & $\begin{array}{ll}\text { - } & \text { income } \\
\text { - } & \text { living area (+ for total waste; - for composting of kitchen waste) } \\
\text { - } & \text { gender } \\
\text { - } & \text { marital status } \\
\text { - } & \text { education } \\
\text { - } & \text { age (- for total waste; + for recycling of refundables) } \\
\text { - } & \text { household members (+ for paper recycling; - for recycling of } \\
\text { - } & \text { pextiles) } \\
\text { - } & \text { time spent on waste management (+ for total waste) } \\
\text { - } & \text { distance to recycling center } \\
\text { - } & \text { attitudinal/behavioural variables (+ for total garbage if } \\
\text { recycling is perceived to be difficult; - for total waste if there is a } \\
\text { positive attitude towards composting and if kitchen waste is } \\
\text { composted; + for composting of kitchen waste if garden waste is } \\
\text { composted; - for composting of kitchen waste if waste } \\
\text { management is perceived to be time-consuming; + for recycling } \\
\text { of textiles if there is attitude about importance of waste) } \\
\text { previous experience with recycling (+ for recycling) } \\
\text { - ease of recycling (+ for recycling of glass, paper, and batteries) } \\
\text { information about waste problems and change in buying } \\
\text { behaviour (+ for paper recycling) }\end{array}$ & $\begin{array}{l}\text { survey data with actual } \\
\text { measurements of waste flows, } 450 \\
\text { households, residential area of } \\
\text { Varberg, Sweden } \\
\text { household survey data from three } \\
\text { Swedish communities with } \\
\text { different fee structures for } \\
\text { recycling component of study }\end{array}$ \\
\hline
\end{tabular}




\begin{tabular}{|c|c|c|c|}
\hline $\begin{array}{l}\text { Authors } \\
\text { (year) }\end{array}$ & Dependent variables & $\begin{array}{c}\text { Independent variables other than policy variables (mostly } \\
\text { demographic characteristics) }\end{array}$ & Data and country \\
\hline $\begin{array}{c}\text { Van Houtven and Morris } \\
\text { (1999) }\end{array}$ & $\begin{array}{ll}- & \text { mixed waste } \\
\text { - } & \text { probability of recycling } \\
\text { - } & \begin{array}{l}\text { total waste (mixed plus } \\
\text { recyclables) }\end{array}\end{array}$ & $\begin{array}{ll}\text { - } & \text { high school education (- for mixed and total wastes) } \\
\text { - } & \text { income (+ for total waste) } \\
\text { - } & \text { dummy for white (+ for recycling) } \\
\text { - } & \text { dummy for urban (-) } \\
\text { - } & \text { dummy for owner-occupied household (+ for recycling) } \\
\text { - } & \text { number of residents by age group (+) } \\
\text { - } & \text { percentage working full-time (- for recycling and total waste) } \\
\text { - } & \text { dummy for importance of waste reduction (- for mixed waste; } \\
\text { - for recycling) } & \text { interaction between unit pricing and home ownership (+ for } \\
\text { - } & \begin{array}{l}\text { interaction between unit pricing and number of residents (- } \\
\text { for mixed and total wastes) }\end{array}\end{array}$ & $\begin{array}{l}\text { survey data with eight actual } \\
\text { measurements of mixed waste and } \\
\text { recyclables per household, } \\
398 \text { households, Marietta, Georgia } \\
\text { (USA) }\end{array}$ \\
\hline
\end{tabular}


TABLE A.3: Summary of available price elasticities

\begin{tabular}{|c|c|c|c|}
\hline Authors (year) & Policy program & Dependent variable & Price elasticity \\
\hline \multirow{20}{*}{ Dijkgraaf and Gradus (2004) } & \multirow{4}{*}{ Weight-based user fee } & Total waste & $-0.47(-0.40)$ \\
\hline & & Unsorted waste & $-0.67(-0.53)$ \\
\hline & & Compostable waste & $-0.92(-0.81)$ \\
\hline & & Recyclable waste & $0.16(0.12)$ \\
\hline & \multirow{4}{*}{$\begin{array}{l}\text { Bag-based user fee } \\
\text { (unsorted + compostable) }\end{array}$} & Total waste & $-0.43(-0.36)$ \\
\hline & & Unsorted waste & $-0.66(-0.51)$ \\
\hline & & Compostable waste & $-0.97(-0.85)$ \\
\hline & & Recyclable waste & $0.25(0.20)$ \\
\hline & \multirow{4}{*}{$\begin{array}{l}\text { Bag-based user fee } \\
\text { (unsorted) }\end{array}$} & Total waste & $-0.14(-0.07)$ \\
\hline & & Unsorted waste & $-0.71(-0.58)$ \\
\hline & & Compostable waste & $0.29(0.40)$ \\
\hline & & Recyclable waste & $0.14(0.09)$ \\
\hline & \multirow{4}{*}{ Frequency-based user fee } & Total waste & $-0.22(-0.16)$ \\
\hline & & Unsorted waste & $-0.28(-0.16)$ \\
\hline & & Compostable waste & $-0.40(-0.31)$ \\
\hline & & Recyclable waste & $0.08(0.04)$ \\
\hline & \multirow{4}{*}{ Volume-based user fee } & Total waste & $-0.06(-0.00)$ \\
\hline & & Unsorted waste & $-0.12(0.01)$ \\
\hline & & Compostable waste & $-0.01(\mathbf{0 . 0 9})$ \\
\hline & & Recyclable waste & $0.01(-0.03)$ \\
\hline \multirow{4}{*}{$\begin{array}{l}\text { Fullerton and Kinnaman } \\
\text { (1996) }\end{array}$} & \multirow{4}{*}{ Bag-based user fee } & Garbage weight & -0.076 \\
\hline & & Garbage volume & -0.226 \\
\hline & & Garbage density & 0.176 \\
\hline & & Recycling weight & 0.073 \\
\hline \multirow{3}{*}{ Hong (1999) } & \multirow{3}{*}{ Bag-based user fee } & Total waste & 0.121 \\
\hline & & Recyclable waste & 0.457 \\
\hline & & Non-recyclable waste & -0.154 \\
\hline
\end{tabular}




\begin{tabular}{|c|c|c|c|}
\hline Authors (year) & Policy program & Dependent variable & Price elasticity \\
\hline \multirow{2}{*}{ Hong and Adams (1999) } & \multirow{2}{*}{ Block payment } & Non-recyclable waste & -0.013 \\
\hline & & Recyclable waste & 0.091 \\
\hline Jenkins (1993) & Bag- or tag-based user fee & Total waste & -0.12 \\
\hline \multirow{2}{*}{$\begin{array}{l}\text { Kinnaman and Fullerton } \\
(2000)\end{array}$} & \multirow{2}{*}{ Bag- or can-based user fee } & Garbage weight & -0.28 \\
\hline & & Recycling weight & 0.22 \\
\hline \multirow{2}{*}{ Linderhof et al. (2001) } & \multirow{2}{*}{ Weight-based pricing } & Compostable waste & $\begin{array}{c}\mathbf{- 1 . 1 0} \text { (short-run) } \\
-\mathbf{1 . 3 9} \text { (long-run }\end{array}$ \\
\hline & & Non-recyclable waste & $\begin{array}{l}-0.26 \text { (short-run) } \\
-0.34 \text { (long-run) }\end{array}$ \\
\hline \multirow{3}{*}{$\begin{array}{l}\text { Morris and Holthausen } \\
\text { (1994) }\end{array}$} & \multirow{3}{*}{ Unit-based fee } & Waste reduction & 0.97 to 1.49 \\
\hline & & Garbage weight & $\mathbf{- 0 . 1 5}$ to $-\mathbf{0 . 6 0}$ \\
\hline & & Recycling weight & $\mathbf{- 0 . 0 0}$ to $\mathbf{- 0 . 5 9}$ \\
\hline Podolsky and Spiegel (1998) & Bag- or tag-based user fee & Total waste per capita & -0.39 \\
\hline Strathman et al. (1995) & Marginal cost pricing & Disposed of garbage & -0.45 \\
\hline $\begin{array}{l}\text { Van Houtven and Morris } \\
\text { (1999) }\end{array}$ & Bag-based pricing & Mixed waste & $\mathbf{- 0 . 1 5}$ to $\mathbf{- 0 . 2 0}$ \\
\hline
\end{tabular}


